\title{
Drug giants turn their backs on RNA interference
}

\section{A once much-touted technique faces a difficult transition to the clinic.}

\section{BY HEIDI LEDFORD}

$\mathrm{N}$ ot long ago, a technique called RNA interference (RNAi) seemed to be on the fast track to commercial success. Its discovery in 1998 revealed a new way to halt the production of specific proteins using specially designed RNA molecules, and it quickly became a favourite tool of basic research. In 2006, the scientists who made the discovery were awarded the Nobel prize for medicine, and the New Jersey-based pharmaceutical giant Merck paid more than US $\$ 1$ billion to snatch up Sirna Therapeutics in San Francisco, California - one of the first biotechnology companies aiming to harness RNAi to create new drugs.

Yet all that seemed like ancient history last week when drugs and diagnostics corporation Roche in Basel, Switzerland - a major investor in RNAi-based drug research - announced it was killing its programme after spending three years and more than $\$ 500$ million on the technique. Although part of a larger restructuring to cut costs, the move is the latest indication that big pharma may be losing faith in RNAi.

"The momentum now seems to be heading a bit against RNAi," says Alan Carr, an analyst at Needham \& Company, an investment-banking firm in New York. Roche's 17 November announcement, which sent stock prices at RNAi companies plunging, came just two months after another Swiss-based multinational, Novartis, declined to spend $\$ 100$ million to extend a partnership with Alnylam, a prominent RNAi company based in Cambridge, Massachusetts.

The development of RNAi-based drugs has stalled as companies confront the challenge of delivering RNA molecules, which are notoriously fragile, to target cells in the human body, and then coaxing those cells to take up the RNA. "Getting these molecules exactly where we want them to go is a little more difficult

\begin{tabular}{|c|c|c|c|}
\hline \multicolumn{4}{|c|}{ A SAMPLING OF RNAI THERAPIES IN CLINICAL TRIALS } \\
\hline Indication & Company & Clinical phase & Delivery method \\
\hline $\begin{array}{l}\text { Age-related macular } \\
\text { degeneration }\end{array}$ & $\begin{array}{l}\text { Quark Pharmaceuticals/ } \\
\text { Pfizer/Silence Therapeutics }\end{array}$ & Phase II & Naked RNA \\
\hline Diabetic macular oedema & Quark Pharmaceuticals/Pfizer & Phase II & Naked RNA \\
\hline HIV & Benitec & Phase I & Lentivirus vector \\
\hline Liver cancer & Alnylam/Tekmira & Phase I & Lipid nanoparticle \\
\hline TTR amyloidosis & Alnylam/Tekmira & Phase I & Lipid nanoparticle \\
\hline Respiratory syncytial virus & $\begin{array}{l}\text { Alnylam/Cubist Pharmaceuticals/ } \\
\text { Kyowa Hakko Kirin }\end{array}$ & Phase II & Inhaled naked RNA \\
\hline
\end{tabular}

than originally thought," says Michael French, chief executive of Marina Biotech, an RNAi company based in Bothell, Washington.

Of the dozen RNAi-based therapeutics in early clinical testing, most apply the RNA molecules directly to the target tissues, or aim to shut down the production of a protein in the liver, which takes up the RNA as it filters the blood (see table). Several candidates also package the RNA within a lipid nanoparticle, a delivery vehicle that both protects the RNA and allows it to be shuttled across cell membranes. Investors expect Alnylam to emerge in the next few years with the first commercially viable RNAi-based therapeutic, which would treat a rare disease called transthyretin amyloidosis - in which an abnormal form of a blood protein is deposited in the nerves and organs - by shutting down the production of the protein in the liver.

Although Alnylam shed about 50 of its 225 employees when its partnership with Novartis ended, chief executive John Maraganore is optimistic. "There's going to be a steady drumbeat of increasing frequency that really validates RNAi as a whole new drug class," he says. "We're feeling pretty damn good about where things are right now."

Until that validation arrives, investors may be wary of the RNAi platform, says Josh Schimmer, an analyst at the investment bank Leerink Swann \& Company in New York. "Alnylam has a very interesting drug at this point," says Schimmer. "It's premature to say they have a very promising platform.'

Companies such as Alnylam have built their business by enticing big pharmaceutical companies in as partners. That strategy has paid off: Alnylam has $\$ 372$ million in cash, an unheardof sum for a young biotechnology company with no drugs yet on the market. But the number of deals with major pharmaceutical firms has slowed, says Carr. "There was a wave of interest earlier on and it's just not there now."

Some holdouts remain. Merck spokeswoman Carolyn Lappetito says her company has not pulled back from RNAi. "It's a long haul," she says. "We have not decided to make any big changes." And although Novartis ended its relationship with Alnylam, the company can now develop the 31 RNAi-based candidate drugs generated during the five-year partnership. In comparison, the three years Roche spent in the field hardly seems enough time to fully evaluate the technique, says Maraganore. "Three years is nothing," he adds. "It's like kicking your three-year-old out of the house and telling him to get a job." -

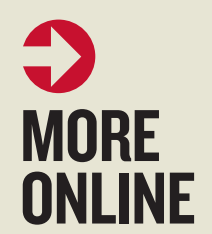

\section{DAILY NEWS}

- Age markers in blood go.nature.com/8emsfx - Coral bleaching goes from bad to worse go.nature.com/uxg2ih

- Funding woes afflict African herbaltherapy institute go.nature.com/wuaujd - Tumours grow their own blood vessels go.nature.com/w82jlp

\section{VIDEO}

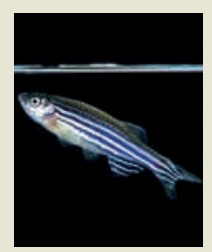

Zebrafish that stop swimming when left without company could be suffering from depression go.nature. com/hwzsrf

\section{ON THE BLOG}

- Scientists respond to ocean acidification doubts go.nature.com/evzraf - Drugs hit teen brains harder go.nature. com/ta4hhj

- Views of Hartley 2 go.nature.com/n2rlha - Animal genomes contain 'skeletons' of ancient viruses go.nature.com/6bkarg 